\title{
Carbonates from the Palaeoproterozoic Sleemanabad Formation, Mahakoshal basin, Central India
}

\author{
Aditi Sharma $^{1}$ and Partha Pratim Chakraborty ${ }^{1,2, *}$ \\ ${ }^{1}$ Department of Geology, University of Delhi, Delhi 110 007, India \\ ${ }^{2}$ Hiroshima Institute of Plate Convergence Area Research, Hiroshima, Japan
}

\begin{abstract}
Facies and facies succession analysis from four sections in a $\sim 12 \mathrm{~m}$ thick carbonate succession, hitherto undescribed, exposed over an east-west transect over $600 \mathrm{~km}$ from the topmost part of the Palaeoproterozoic Sleemanabad Formation, Mahakoshal Group, Central India reveals facies development in a proximal-distal relation. The facies types include microbialite and stromatolite, interbedded limestone-mudstone, intraclastic conglomerate, pyrite bearing dark-coloured limestone and massive/normal-graded conglomerate and fine-grained sandstone. While microbialites and isolated stromatolites (rarely conjoined) with seafloor precipitate are interpreted as a product of proximal peritidal deposition, the dark-coloured pyrite bearing limestone represents the distal platform deposition below storm wave base.
\end{abstract}

Keywords: Carbonate succession, facies types, mass flow, proximal-distal relation.

THE Proterozoic Eon (2500-541 Ma) ${ }^{1}$ encompasses more than $40 \%$ of the Earth's history and represents a unique time that witnessed amalgamation and break-up of supercontinents $^{2}$, dramatic oceanic and atmospheric changes, including oxygenation ${ }^{3}$ and biological evolution leading to multicellular life ${ }^{4}$. None of these changes followed uniform, steady character; for example, Palaeoproterozoic (2500-1800 Ma) and late Neoproterozoic (800-541 Ma) witnessed major biological, tectonic, climatic and atmospheric changes ${ }^{5}$. Chemical sediments, viz. carbonate, phosphorite and banded iron formation (BIF) allow decoding of the events in early Earth's history. Precambrian carbonate sediments, formed by a variety of abiotic and microbial processes, register depositional control determined by tectonic, eustatic and climatic processes. In the absence of Phanerozoic analogue, Precambrian carbonates are studied and interpreted in a non-actualistic manner and hence, allow us to unravel nuances of shallow marine carbonate deposition prior to the appearance of calcareous microplanktons. Further, the early Protero-

\footnotetext{
*For correspondence. (e-mail: parthageology@gmail.com)
}

zoic denotes the first undisputed 'Supercontinent' cycle marked by the formation of supercontinent 'Columbia' at around $1.9-1.8 \mathrm{Ga}$ with development of carbonate platforms at its margins ${ }^{6}$. Carbonates formed in shallow water at elevated sea level and higher carbonate saturation are dominated by inorganic precipitates and microbialites, a non-skeletal organo-sedimentary deposit formed by the benthic microbial community. Unlike Archean and Neoproterozoic carbonates, Palaeoproterozoic carbonates are restricted in occurrence and described principally under peritidal setting ${ }^{6-12}$.

The Palaeoproterozoic Sleemanabad Formation, Mahakoshal Group, Central India exposes a $\sim 12$ m thick carbonate succession at its uppermost part that allows the documentation of carbonate deposition in an active margin setting. In this study, we describe the carbonate succession and its spatio-temporal build-up to delineate: (i) the lithofacies, hitherto undescribed, in a proximaldistal relation, and (2) palaeogeographic shifts in space and time.

\section{Background of the study area}

The Palaeoproterozoic Mahakoshal basin is an ENEWSW trending, fault-controlled rift basin in northern part of the Central Indian Tectonic Zone (CITZ; Figure $1 a$ ). Represented by a thick metasedimentary lithosuccession with substantial amounts of metavolcanics ${ }^{13}$, the Mahakoshal Group is demarcated by the Son-Narmada North Fault (SNNF) in the north and the Son-Narmada South Fault (SNSF) in the south. Main rock types are quartzite, carbonate, pyroclastics, chert, BIF, greywacke-argillite, mafic and felsic volcanics ${ }^{13-15}$. Roy and Devarajan ${ }^{16}$ proposed a three-tier stratigraphy, viz. Sleemanabad Formation, Parsoi Formation and Dudhmania Formation, in the order of superposition. While the Sleemanabad and Dudhmania formations are dominated by meta-argillites, the Parsoi Formation is dominantly meta-arenites. In alternation with phyllite and fine-grained meta-arenite, variably thick (centimetres to metres thick) carbonate lithopackages, discussed herein, are present at the topmost part of the Sleemanabad Formation. 


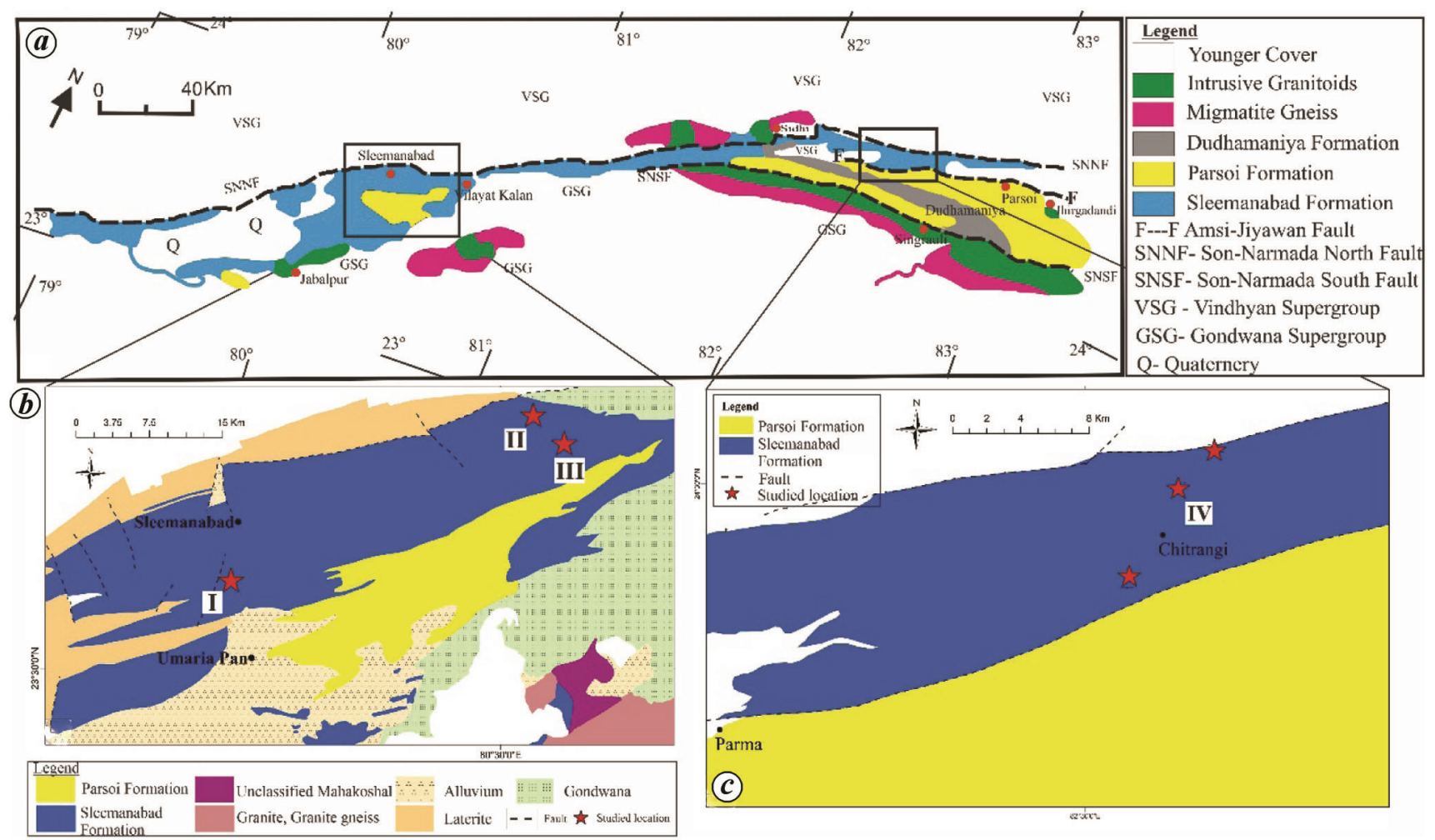

Figure 1. (a) Geological map of the Mahakoshal basin (after ref. 16) with the locations marked in both (b) eastern and (c) western sections.

\section{Materials and methods}

Sections were studied in an east-west transect. In total four sections, including Bhanpura Kalan (I), Rupond (II), Datla Pond (III) in the west (Figure $1 b$ ) and Chitrangi Section (IV) in the east (Figure $1 c$ ) of the basin were studied. While carbonate facies types were categorized based on lithology and primary sedimentary structures, clastic units were described on the basis of lithology (grain size and sorting), sedimentary structure and grading type (normal, reverse, etc.).

\section{Results}

The carbonate facies varieties include microbialite and stromatolites with isolated and conjoined columns, buffcoloured bedded lithographic limestone-shale alternation, intraclastic conglomerate and pyrite bearing darkcoloured limestone, whereas the clastic varieties include polymictic conglomerate and normal-graded sandstone. Bounded between phyllite, the best developed limestone section is noticed at the Rupond section.

\section{Facies I-microbialite and stromatolite}

This facies is recorded in two morphological forms, viz. (a) stratiform and (b) biohermal. Tabular bodies internally made up of low relief, stratiform laminae with tens of metres of lateral continuity constitute the microbialite unit. Although laminites are dominantly characterized by thin planar to undulatory laminations, locally they also arch to form small stromatolites (tufa; Figure $2 a$ ). Also, laminations with low-relief microbial highs are often found inclined without any preferred orientation. Irregular micrite-sparite laminae with low to moderate lateral continuity characterize these units under the microscope (Figure $2 b$ ). At times, upward divergent fans of (centimetres long) aragonite crystals, pseudomorphed as dolomite, form the microdigited laminations (Figure $2 c$ ). In comparison, the biohermal stromatolites are found in three morphological forms: (i) isolated, unlinked column, (ii) conjoined and linked columns, and (iii) large isolated bulbous domes that coalesce upward to give close-linked hemispheroids (Figure $2 d$ ). In the biohermal forms, columns are mostly club-shaped and their internal laminations terminate against the column margins (Figure $2 e$ ). The column height and head diameter in types (i) and (ii) are $4-28 \mathrm{~cm}$ and $4-20 \mathrm{~cm}$ respectively, and the same for type (iii) are 12-15 and 10-12 cm respectively.

A $\sim 8 \mathrm{~m}$ thick fortuitous section near Rupond village, south of Katni district, Madhya Pradesh offers the best exposure of this facies. The section reveals well-developed colonies of domal, columnar stromatolites successively followed upward by algal laminites and further upward by microbialite with rare, isolated columns and 


\section{RESEARCH ARTICLES}

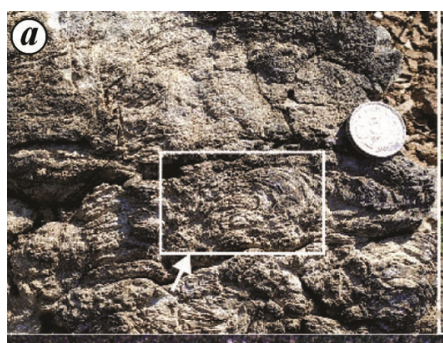

(b)
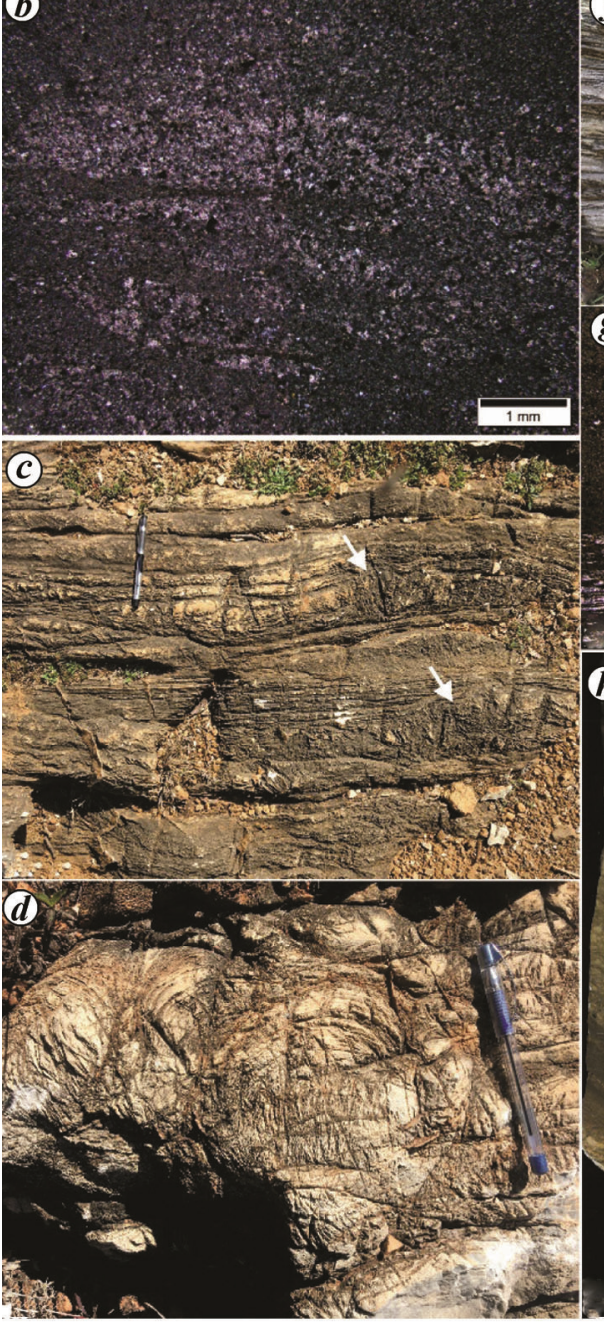

Figure 2. $\boldsymbol{a}$, Microdigitate (tufa) stromatolite (arrowed, enboxed), b, Photomicrograph showing laterally discontinuous alternate layers of micrite and microsparite. $\boldsymbol{c}$, Radial fans of aragonite, pseudomorphed as dolomite (arrow). $\boldsymbol{d}$, Stromatolites: domal, bulbuous. $\boldsymbol{e}$, Microbialites with small columns of stromatolites. $\boldsymbol{f}$, Interbedded limestone shale. $g$, Photomicrograph showing pyrite growth transecting micrite-sparite contact. $\boldsymbol{h}$, Polished hand specimen showing clast-supported mass flow with coarse-tail grading. Note scour (arrow) at the base of massflow. $\boldsymbol{i}$, Sub-type-I of thick mass flow showing matching boundaries between intraclasts. $\boldsymbol{j}$, Sub-type-II stream of uniformly aligned intraclasts. $\boldsymbol{k}$, Photomicrograph showing growth of pyrite encircling micrite groundmass and inclusion of micrite within pyrite (arrow). $\boldsymbol{l}$, Polymictic conglomerate $(C)$ overlain by chlorite-bearing feldspathic sandstone.

microdigitate (tufa) stromatolites ${ }^{6}$. On closer examination and with detailed sketching, we noticed an ill-defined cyclicity in this section defined by an increase in microbial laminae thickness (Figure 3). Two decimetre-thick cycles have been recorded with upward increase in laminae thickness from 12 to $80 \mathrm{~mm}$ and 10 to $70 \mathrm{~mm}$. Interestingly, the development of small, isolated stromatolite columns is noticed at the beginning of each cycle, which did not continue upward.

\section{Facies II - Interbedded limestone and mudstone}

Either as amalgamated beds or in alternation with shale, decimetre- to metre-thick beds of lithographic limestone constitute this facies. The best development is noted in the Datla Pond section with a thickness of $5.6 \mathrm{~m}$ (Figure $2 f$ ). Limestones in this facies are reddish-brown, green or grey in colour, tabular in bed geometry and internally massive or evenly plane-laminated (laminations $1-2.5 \mathrm{~cm}$ 

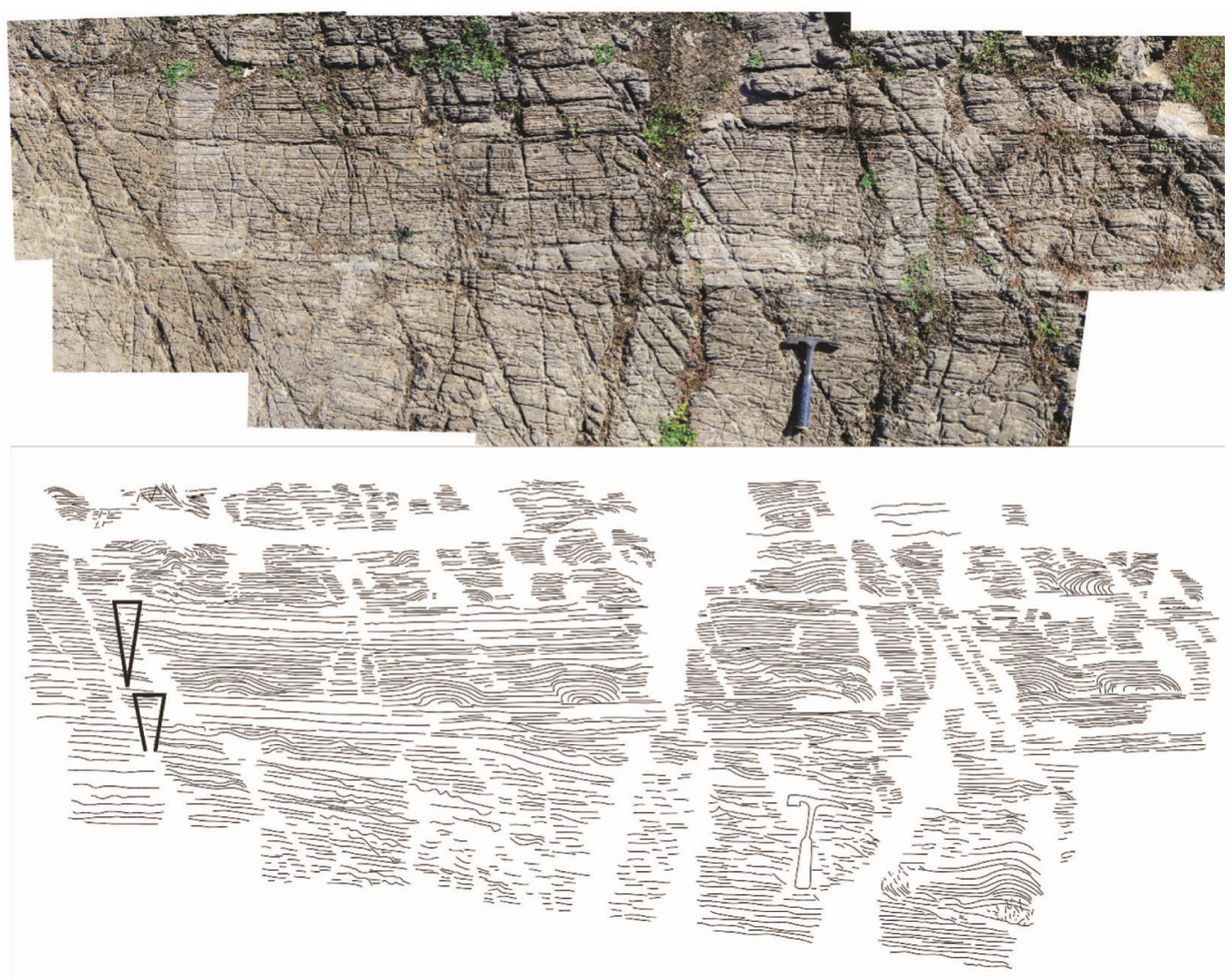

Figure 3. Field photograph and sketch thereof illustrating microbialite with isolated columns of stromatolite from the Rupond section. Note depositional cycles defined by the increase in microbial laminae thickness.

thick). Under the microscope, limestones are aphanitic micrite (structureless, lacking in grain, lamination or clot fabric, etc.) with scattered, irregularly shaped fenestrae up to $0.3 \mathrm{~mm}$ long, filled with micro-spar carbonate and/or quartz. Isolated cuboidal pyrite gains are noted transecting micrite and micro-spar boundaries (Figure $2 g)$.

\section{Facies III - Intraclastic carbonate conglomerate}

Centimetre to decimetre-thick units of this wackestonepackstone facies are recorded in the Bhanpura Kalan section in alternation with microbial and laminated limestone (facies I). Centimetres thick units (average thickness $2.6 \mathrm{~cm})$, internally clast-supported with coarse-tail grading (Figure $2 h$ ) are recorded in alternation with millimetre-thick, plane-laminated limestone. Light buffcoloured silt-sized tabular clasts, derived from underlying plane laminated micritic limestone, define size- and concentration-grading. Relatively larger tabular clasts are characteristically bed-parallel. The base of the beds is erosional with the presence of asymmetric scoops and fractures. The average width and depth of the scoop are $1 \mathrm{~cm}$ and $3 \mathrm{~mm}$ respectively. Infiltration of mass-flow materials within the fractures is noticed in some cases. At times, tabular clasts at the basal part of these units showed edgewise arrangement.

A thicker (average thickness $12 \mathrm{~cm}$ ) counterpart of this facies is represented by tabular to laterally wedging beds with two different sub-types; one laterally giving way to the other. In subtype-I, encased within light-coloured groundmass, stacks of dark-coloured bed-parallel tabular intraclasts are present with matching boundaries (Figure $2 i$ ). The clast-bearing unit is often found laterally grading into an undisturbed bed. In contrast, subtype-II is an intraclastic conglomerate with a stream of intraclasts uniformly aligned, not necessarily parallel to the bed (Figure $2 j$ ). Clasts are mostly elliptical and in high concentration without any signature of grading. The lower boundaries of these units are planar and non-erosional.

\section{Facies IV-Pyrite-bearing dark-coloured limestone}

Thinly bedded, dark-coloured limestone represents this facies and is recorded from the easternmost extremity of the studied stretch, i.e. the Chitrangi section. The maximum recorded thickness is $10 \mathrm{~m}$. Within outcrop limitation, the facies is with laterally traceable lamination for a couple of metres. Pyrite grains as stringer, framboid or euhedra are noticed within the micritic groundmass. 


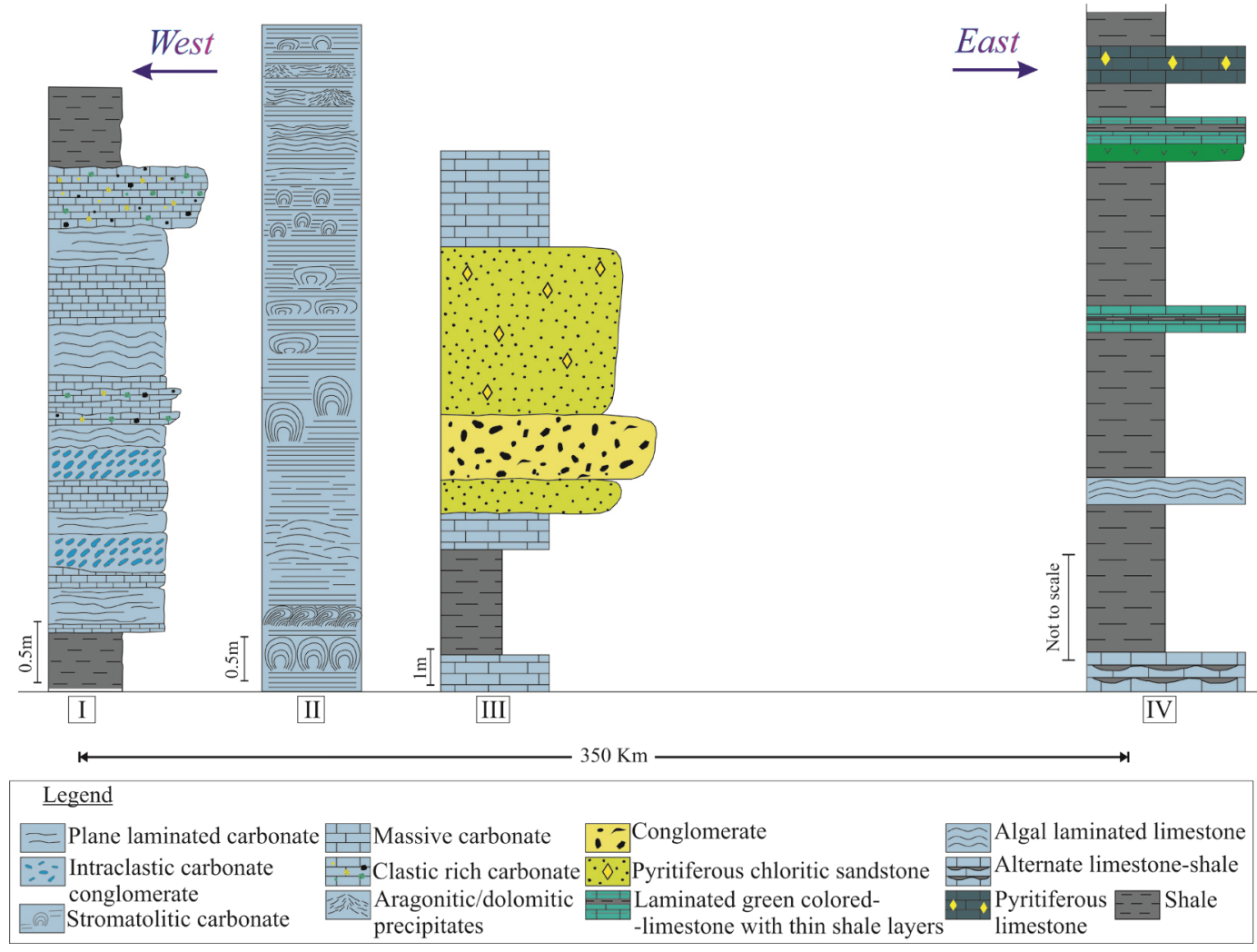

Figure 4. Facies development in an east-west transect. Note eastward increase in argillite: carbonate ratio. Also note the presence of siliciclastic package at the Datla Pond section.

Rarely, pyrite growth encircling micrite groundmass and inclusion of micrite within euhedral pyrite (Figure $2 k$ ) suggest a displacive growth for pyrite.

\section{Facies V-Massive/normal-graded fine-grained chlorite-bearing sandstone}

This facies unit is exposed only at the Datla Pond section intervening facies II limestone, where the maximum facies thickness is $5 \mathrm{~m}$. Beds of matrix-supported planar-based polymictic conglomerate and normal-graded chloritepyrite bearing sandstone constitute this facies (Figure $2 l$ ). Clasts within the conglomerate are composed of quartzite and basalt, highly stretched, elongated parallel to the bedding plane and embedded in a sandy matrix. The maximum clast size is $4 \mathrm{~cm}$. The interbedded, fine-grained, feldspathic sandstone unit is $45 \mathrm{~cm}$ thick and internally shows concentration- and size-grading of clast. Overall, the sandstone unit shows a fining-upward character and gradational relationship with overlying argillite (phyllite). Chlorite grains are present either as authigenic, finegrained, interstitial material or as a sand-sized framework.

\section{Discussion}

Precambrian rimmed platforms and ramps are spectacularly similar with modern analogues in terms of facies development. They also show illustrative dissimilarity in terms of the presence of seafloor precipitates, giant ooids or molar tooth structure. This dichotomy makes Precambrian carbonates special. Documentation of carbonate facies types in the four studied sections of the Sleemanabad Formation reveals spatial variability in facies development in an east-west transect (Figure 4).

Microbial laminites (facies I), massive limestone (clastic-rich at times) and thick-bedded intraclastic conglomerate (facies III) represent the westernmost Bhanpura Kalan section. Laterally persistent, crinkly laminated character represents deposition in a regional quiescent environment in peritidal to shallow intertidal setting ${ }^{6,17}$. In these environments, laminites commonly record a combination of precipitation of fine-grained carbonate with benthic microbial mats and trapping of detrital sediment $^{8,9,18}$.

Intraclastic conglomerate interbeds at this section are with varied origin, thickness, rheology and depositional motif. Scoops and fractures at the base of thin units suggest flows with strong basal shear. The clasts generated from the substrate as a result are tabular and dominantly bed-parallel ${ }^{19-21}$. While the grading indicates deposition from turbulent suspension, the bed-parallel clast arrangement suggests laminar condition ${ }^{22}$. It is suggested that the coarse-tail grading is not imparted by vertical settling, but because of clast incorporation at the bottom ${ }^{17}$. 
The edgewise clast arrangement is a result of interaction between shear generated by basal friction and gravitation pull on clasts owing to elevation difference in basal scoop. In contrast, stacks of tabular intraclasts with matching clast boundaries in subtype-I of thicker beds are formed by in situ intrastratal brittle fracturing. Due to early lithification and hardening, limestone often behaves in a brittle manner near the depositional surface. Thicker conglomerate beds with planar, non-erosional base and highangle clast alignment with bed boundary in subtype-II are products of high-concentration sediment gravity flow. High-angle clast orientation may be because of some localized vortex that was dissipated quickly. Interbedded with shallow water microbialite (facies I), carbonate intraclasts possibly formed by desiccation or wave reworking (subtype-I) and, in turn, deposited as intraclastic mass flows (thick subtype-II and thin units) ${ }^{23}$.

Moving eastward, the Rupond village section exposes a shallowing-upward succession with domal stromatolites that give way upward to algal laminates with seafloor precipitates and microbialites with struggling upcurved stromatoporoids, rarely conjoined. Domal/columnar stromatolites, with club-shaped symmetrical columns of variable width and height suggest relatively higher bathymetry without much wave or current action ${ }^{24,25}$. Isolated small columns commonly form in a high-energy stressed environment and with decrease in energy, domes and columns are formed with linked clusters. Upward in the section, crinkly algal laminite dominates with occurrence of centimetres-thick divergent aragonite fans, pseudomorphs preserved as dolomite, suggesting the role of seafloor precipitation. Seafloor precipitates (encrustation), in the form of aragonite and calcite pseudomorphs, are reported from both Archean and Palaeoproterozoic shallow and open marine carbonates, including stormdominated shelves and reef rimming platforms ${ }^{26,27}$. The shallowing-upward character is well manifested in the wavy and crinkly algal microlaminites and microdigitate stromatolites (tufa) in the upper part of the section; identified as products of stratiform, benthic microbial mat within shallow-water protected lagoon or inner ramp peritidal setting ${ }^{6,25,28,29}$.

Further east at the Datla Pond section, micritic facies II limestone with even beds, fenestrae structure and near absence of siliciclastics, wave or tide features suggest deposition in a low-energy intertidal to subtidal condition $^{30}$. Though rare in the Phanerozoic, bedded micritic carbonates abundantly formed in intertidal setting at high levels of seawater carbonate saturation (analogous to 'whitings ${ }^{\text {,31) }}$ in both Palaeo- and Mesoproterozoic $\mathrm{era}^{32,33}$. The formation of fenestrae in this backdrop is not clear, though Shinn ${ }^{34}$ reported their presence in subtidal calcarenites.

Intervening facies II succession, the siliciclastic (facies V) deposit at the Datla Pond section is interesting, and more so, in absence of its shallow-water counterpart in proximal sections. While matrix-supported conglomerate with planar base and floating clasts is a product of highconcentration mass flow, the normal-graded, finingupward sandstone is identified as a deposit from relatively low-concentration turbulent fluidal flow where grains were entrained by turbulence ${ }^{19,35}$. Together conglomerate and sandstone are interpreted as sediment gravity flows of different rheology. The occurrence of chlorite and pyrite in association may be a result of substitution of $\mathrm{Fe}^{2+}$ in initially Fe-rich chlorite by $\mathrm{Mg}^{2+}$ in a sulphidic diagenetic environment, where the released $\mathrm{Fe}^{2+}$ combines with $\mathrm{S}^{2-}$ to form pyrite ${ }^{36}$. We intend to connect facies $\mathrm{V}$ as rootless distal delta lobe deposit supplied from a distant dirty river with hyperpycnal discharge. Forced trapping of sand at the feeder mouth and its intermittent hyperpycnal release may result in the deposition of such rootless mouth bars in a mid-ramp setting $^{37,38}$.

On the extreme east near Chitrangi, limestone beds are thin, structureless, massive to plane-laminated (facies IV), green to fleshy in colour, pyrite bearing and interbedded with thick argillites. From displaced growth, pyrites are interpreted as early diagenetic in origin in an euxinic depositional condition with high sulphur fugacity. From (i) the absence of any wave or current feature, (ii) laterally persistent lamination pattern, (iii) micritic lithology, (iv) dark grey to black colour and (v) presence of early diagenetic pyrite, this facies is modelled as deepest water bathymetry in a distal ramp setting, below storm wave base ${ }^{29}$.

Definitive trends noticed from west to east are: (i) increase in argillite (phyllite) : carbonate ratio; (ii) decrease in clastic content, except for the presence of a depositional lobe at the Datla Pond section; (iii) confinement of microbialites and stromatolites in the western sections and pyrite in the easternmost section, and (iv) confinement of desiccation-triggered intraclastic conglomerates at the westernmost Bhanpura Kalan section. Collation of all evidences allowed us to infer that the carbonate ramp system developed in the upper part of the Sleemanabad Formation had its proximal part in the west and distal (deeper) part in the east (Figure 5). A stressful proximal ramp did not allow full-scale growth of the stromatolite colony. Analogous facies motif with depth-partitioned microbialite development in low-gradient ramp has also been documented from the Palaeoproterozoic Vempalle Formation in Cuddapah basin ${ }^{39}$.

\section{Conclusion}

Despite the domination of metasediments over metavolcanics in volume and aerial extent, the Mahakoshal Group has rarely drawn the attention of sedimentologists. Present in the topmost part of the Sleemanabad Formation, a $\sim 12 \mathrm{~m}$ thick carbonate succession documents facies types of a carbonate platform developed in a 


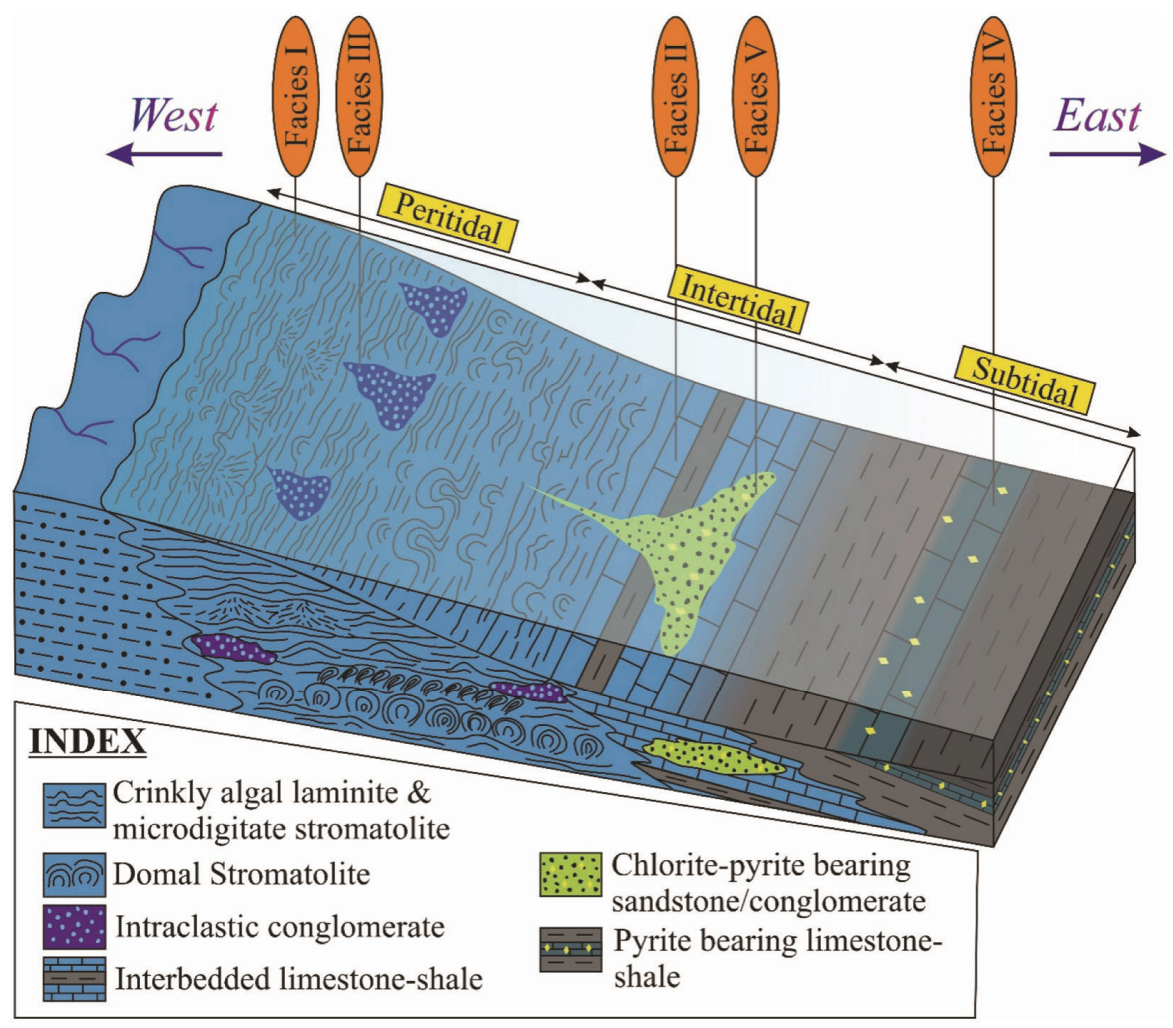

Figure 5. A cartoon illustrating facies development pattern in Sleemanabad carbonate ramp.

Palaeoproterozoic rift setting. From the demonstration of facies and facies succession development in four sections spread over an east-west stretch of $600 \mathrm{~km}$, we have documented the presence of microbialites and stromatolites, interbedded limestone and shale, intraclastic conglomerate and pyrite bearing dark-coloured limestone in a proximal (west)-distal (east) relation. Besides, the present study also enabled us to infer the east-southeastward opening for the Mahakoshal Sea. Intraclasts generated by desiccation in proximal peritidal setting participated in subsequent wave reworking and gave rise to carbonate mass flows of varying rheology.

1. Gradstein, F. M. et al. (eds), The Geologic Time Scale, Elsevier, 2012, p. 1145 .

2. Dalziel, I. W., Overview: Neoproterozoic-Paleozoic geography and tectonics: review, hypothesis, environmental speculation. Geol. Soc. Am. Bull., 1997, 109(1), 16-42.

3. Hoffman, P. F., Kaufman, A. J., Halverson, G. P. and Schrag, D. P., A Neoproterozoic snowball Earth. Science, 1998, 281(5381), $1342-1346$

4. Knoll, A. H., Proterozoic and Early Cambrian protists: evidence for accelerating evolutionary tempo. Proc. Natl. Acad. Sci. USA, 1994, 91(15), 6743-6750.

5. Chakraborty, P. P., Tandon, S. K., Roy, S. B., Saha, S. and Paul, P. P., Proterozoic sedimentary basins of India. In Geodynamics of the Indian Plate (Gupta, N. and Tandon, S. K.), Springer, Switzerland, 2020, pp. 145-178.

6. Grotzinger, J. P., Facies and evolution of Precambrian carbonate depositional systems: emergence of the modern platform arche- type. In Controls on Carbonate Platform and Basin Development, Society for Sedimentary Geology Special Publication, Arizona, USA, 1989, vol. 44, pp. 79-106.

7. Grey, K. and Thorne, A. M., Biostratigraphic significance of stromatolites in upward shallowing sequences of the early Proterozoic Duck Creek Dolomite, Western Australia. Precambrian Res., 1985, 29(1-3), 183-206.

8. Grotzinger, J. P., Evolution of Early Proterozoic passive-margin carbonate platform, rocknest formation, Wopmay orogen, Northwest Territories, Canada. J. Sediment. Res., 1986, 56(6), 831-847.

9. Grotzinger, J. P., Cyclicity and paleoenvironmental dynamics, Rocknest platform, northwest Canada. Geol. Soc. Am. Bull., 1986, 97(10), 1208-1231.

10. Grotzinger, J. P. and Read, J. F., Evidence for primary aragonite precipitation, lower Proterozoic $(1.9 \mathrm{Ga})$ Rocknest dolomite, Wopmay orogen, Northwest Canada. Geology, 1983, 11(12), $710-713$.

11. Hofmann, H. J. and Jackson, G. D., Proterozoic ministromatolites with radial-fibrous fabric. Sedimentology, 1987, 34(6), 963-971.

12. Sami, T. T. and James, N. P., Synsedimentary cements as Paleoproterozoic platform building blocks, Pethei Group, northwestern Canada. J. Sediment Res., 1996, 66(1), 209-222.

13. Roy, A. and Bandyopadhyay, B. K., Cleavage development in Mahakoshal group of rocks of Sleemanabad-Sihora area, Jabalpur district, Madhya Pradesh. Indian Miner., 1990, 44(2-3), 111-128.

14. Roy, A. and Bandyopadhyay, B., Tectonic and structural pattern of the Mahakoshal belt of central India: a discussion. Geol. Surv. India Spec. Publ., 1990, 28, 226-240.

15. Thakur, K. S. and Shukla, R. S., Geochemistry of early proterozoic metabasites and associated copper mineralisation in Karaudiya area in Mahakoshal rift Basin, Shahdol district, Madhya Pradesh. Geol. Surv. India Spec. Publ., 1990, 28, 512-526. 
16. Roy, A. and Devarajan, M. K., A reappraisal of the stratigraphy and tectonics of the Palaeoproterozoic Mahakoshal supracrustal belt, Central India. Geol. Surv. India Spec. Publ., 2000, 57, 79-97.

17. Chakraborty, P. P., Slides, soft-sediment deformations, and mass flows from Proterozoic Lakheri Limestone Formation, Vindhyan Supergroup, central India, and their implications towards basin tectonics. Facies, 2010, 57(2), 331-349.

18. Hamon, Y. and Merzeraud, G., Facies architecture and cyclicity in a mosaic carbonate platform: effects of fault-block tectonics (Lower Lias, Causses platform, south-east France). Sedimentology, 2008, 55(1), 155-178.

19. Bera, M. K., Sarkar, A., Chakraborty, P. P., Loyal, R. S. and Sanyal, P., Marine to continental transition in Himalayan foreland. Geol. Soc. Am. Bull., 2008, 120(9-10), 1214-1232.

20. Mutti, E. and Normark, W. R., Comparing examples of modern and ancient turbidite systems: problems and concepts. In Marine Clastic Sedimentology, Springer, Dordrecht, The Netherlands, 1987, pp. 1-38.

21. Mutti, E., Tinterri, R., Benevelli, G., di Biase, D. and Cavanna, G., Deltaic, mixed and turbidite sedimentation of ancient foreland basins. Mar. Pet. Geol., 2003, 20(6-8), 733-755.

22. Enos, P., Flow regimes in debris flow. Sedimentology, 1977, 24(1), 133-142.

23. Sarkar, S., Chakraborty, P. P. and Bose, P. K., Multimode generation of carbonate tabular intraclast deposits: unnamed proterozoic formation, Maharashtra. J. Geol. Soc. India, 1994, 43(4), 415423.

24. Beukes, N. J. and Lowe, D. R., Environmental control on diverse stromatolite morphologies in the 3000 Myr Pongola Supergroup, South Africa. Sedimentology, 1989, 36(3), 383-397.

25. Sarkar, S., Chakraborty, P. P. and Bose, P. K., Proterozoic Lakheri limestone, central India: facies, paleogeography and physiography. In Recent Adv. Vindhyan Geol. (ed. Bhattacharya, A.), Journal of Geological Society India Memoir, Bangalore, 1996, no. 36, pp. 5-25.

26. Grotzinger, J. P. and James, N. P., Precambrian carbonates: evolution of understanding. In Carbonate Sedimentation and Diagenesis in the Evolving Precambrian World (eds Grotzinger, J. P. and James, N. P.), Society for Sedimentary Geology Special Publication, 2000, vol. 67, pp. 3-20.

27. Pope, M. C. and Grotzinger, J. P., Controls on fabric development and morphology of tufas and stromatolites, uppermost Pethel Group (1.8 Ga), Great Slave Lake, northwest Canada. In Carbonate Sedimentation and Diagenesis in the Evolving Precambrian World (eds Grotzinger, J. P. and James, N. P.), Society for Sedimentary Geology Special Publication, 2000.

28. Pratt, B. R., James, N. P. and Cowan, C. A., Peritidal carbonates. In Facies Models: Response to Sea Level Changes (Walker, R. G. and James, N. P.), Geological Association of Canada, St John's, Newfoundland, 1992, pp. 303-322.
29. Sarkar, S. and Bose, P. K., Variations in Late Proterozoic stromatolites over a transition from basin plain to nearshore subtidal zone. Precambrian Res., 1992, 56(1-2), 139-157.

30. Sarkar, S., Banerjee, S., Samanta, P. and Jeevankumar, S., Microbial mat-induced sedimentary structures in siliciclastic sediments: examples from the 1.6 Ga Chorhat Sandstone, Vindhyan Supergroup, MP, India. J. Earth Syst. Sci., 2006, 115(1), 49-60.

31. Grotzinger, J. P. and Knoll, A. H., Stromatolites in Precambrian carbonates: evolutionary mileposts or environmental dipsticks? Annu. Rev. Earth Planet. Sci., 1999, 27(1), 313-358.

32. Bartley, J. K., Knoll, A. H., Grotzinger, J. P. and Sergeev, V. N., Lithification and fabric genesis in precipitated stromatolites and associated peritidal carbonates, Mesoproterozoic Billyakh Group, Siberia. In Carbonate Sedimentation and Diagenesis in the Evolving Precambrian World (eds Grotzinger, J. P. and James, N. P.), Society for Sedimentary Geology Special Publication, 2000, vol. 67, pp. 59-73.

33. Sumner, D. Y. and Grotzinger, J. P., Herringbone calcite; petrography and environmental significance. J. Sediment Res., 1996, 66(3), 419-429.

34. Shinn, E. A., Birdseyes, fenestrae, shrinkage pores, and loferites; a reevaluation. J. Sediment. Res., 1983, 53(2), 619-628.

35. Mishra, S. R., Sharma, A., Chakraborty, P. P., Mohanty, S. P. and Tripathi, S. C., Mixed carbonate-siliciclastic sedimentation in the Upper Cretaceous Nilkanth Formation, Garhwal Himalaya, India. J. Earth Syst. Sci., 2020, 129(1), 1-14.

36. Morad, S., Pyrite-chlorite and pyrite-biotite relations in sandstones. Sediment. Geol., 1986, 49(3-4), 177-192.

37. Chakraborty, P. P., Saha, S. and Das, K., Record of continental to marine transition from the Mesoproterozoic Ampani basin, Central India: an exercise of process-based sedimentology in a structurally deformed basin. J. Asian Earth Sci., 2017, 143, 122-140.

38. Wright, L. D., Sediment transport and deposition at river mouths: a synthesis. Geol. Soc. Am. Bull., 1977, 88(6), 857-868.

39. Chakrabarti, G., Shome, D., Kumar, S., Stephens G. M. and Kah, L. C., Carbonate platform development in a Paleoproterozoic extensional basin, Vempalle Formation, Cuddapah Basin, India. J. Asian Earth Sci., 2014, 91, 263-279.

ACKNOWLEDGEMENTS. A.S. thanks University Grants Commission, New Delhi for financial support in the form of a fellowship. We thank the Department of Geology, University of Delhi for infrastructural support.

Received 2 January 2021; revised accepted 29 July 2021 